\title{
Skrifgebruik en samelewing Die Apostoliese Geloofsending van Suid-Afrika
}

\author{
W.J. Wessels \\ Departement Ou Testament \\ UNISA \\ PRETORIA
}

\begin{abstract}
This anicle is an attempt to describe the use of the Bible in the Apostolic Faith Mission of South Africa $(A F M)$. From the early stages of the church's humble beginnings, the use of Scripture changed in accordance with the social and intellectual development of its members. In the earty stages there secmed to have been a mon spontaneous interaction with the Bible which later made way for a more angumentative approach. Factors like the development of a centralised church system and the need to be accepted in the local church society in the country had a definite influence on the use of Scripturc. Although strong emphasis was placed on the experiental aspect of faith, some of the leading members felt the nced for theological training. Those who felt this need studied mostly at Reforned faculties which undeniably influenced their view of Scripture. From a spontaneous application of the Bible in the everyday life of the believer, a more formal attitude has developed towards the Bible and its application. From the research it is clear that there is a noticeable correlation between the use of Scripture in the AFM and the society in which the church finds itself.
\end{abstract}

\section{INLEIDEND}

Hierdie artikel handel oor die Skrifgebruik van die Apostoliese Geloofsending van Suid-Afrika (AGS) binne bepaalde samelewingsomstandighede. Die klem lê veral op die jare voor die sewentigs. Min studie uit eie geledere is tot op hede oor hierdie onderwerp gedoen. Vanuit ander geledere is daar geskryf oor die AGS in die besonder, maar ook oor die Pinksterbeweging in Suid-Afrika (vgl. van Staden, 1980 asook die versamelbundel van die Instituut vir Reformatoriese Studies, 1986). Dit bly moeilik om 'n kerk se gebruik van die Skrif te beskryf en daar moet noodgedwonge veralgemeende uitsprake gelewer word om sinvol daaroor te kan praat. Hierdie artikel is 'n poging om die waargenome tendense weer te gee, om denke daaroor te stimuleer en verdere studie aan te moedig. Die primêre oogmerk van die studie is om te beskryf en nie om te polemiseer nie. Die skrywer is egter deeglik daarvan bewus dat die seleksie en interpretasie van feite gedoen is vanuit 'n eie verwysingsraamwerk en dus reeds meer is as net om te beskryf.

Die Apostoliese Geloofsending van Suid-Afrika (AGS van SA) het rondom die jaar 1908 sy beslag in Suid-Afrika gekry. Dié kerk was nie 'n skeurkerk uit ander kerke nie, maar 'n stigting wat ontstaan het uit 'n spontane saamgroepering van mense wat ooreenstemmende godsdienstige behoeftes en later 'n gemeenskaplike godsdienstige 
ervaring gedeel het. Leiding is aanvanklik deur persone uit die Verenigde State van Amerika geneem, maar sedert ongeveer 1913 het die leierskap van die beweging oorgegaan in die hande van plaaslike persone. Wanneer gevra word na die Bybelgebruik van die AGS, moet seer sekerlik wat die ontstaansjare betref, na buitelandse, sowel as na inheemse invloede gekyk word.

\section{INVLOEDRYKE BUITELANDSE GEBEURE EN PERSONE}

Verskeie omvangryke studies het in die onlangse verlede verskyn wat die ontstaansagtergrond en klimaat beskryf waarteen die totstandkoming van ' $n$ Pinksterbeweging soos die AGS van Suid-Afrika gesien moet word en daarom word dit nie hier bespreek nie (vgl. Möller, 1975; Van der Spuy, 1985, Du Plessis, 1986 en Burger, 1987). Dit is egter van belang om te meld dat invloed uitgegaan het van die Piëtisme, die sogenaamde Tweede Evangeliese Ontwaking in Amerika (1857/58), die Heiligheidsbeweging in Amerika (1861-1865) en die Sionistebeweging van John Alexander Dowie. Van Dowie se volgelinge, soos onder andere John G. Lake en Tom Hesmalhalch het van die eerste leiers van die Pinksterbeweging in Suid-Afrika geword. Hulle het sterk klem gelè op 'n bediening van genesing en die siening dat godsdiens ervaar moes word.

Bovermelde figure het die Bybel gesien as 'n bron waaruit inligting onttrek en gesistematiseer moes word. Die waarheid wat $s \delta$ ontdek is, is as 'n waarheid vir hulle tyd aanvaar, soos die geval was met die vervulling of doop met die Heilige Gees (vgl. Burger, 1987:66-71). Dié wyse van omgang met die Bybel is voortgesit onder die lede van die Pinksterbeweging in Suid-Afrika. Die waarhede van die Skrif is deur eie ervaring bevestig (vgl. Gaede, 1989:80).

\subsection{John G. Lake}

Hierdie eertydse Metodiste-predikant het na 'n loopbaan in die koerantwese en sakewêreld in 1901 by Dowie in Sionstad aangesluit. Hy was veral deur die genesingsbediening aangetrek (vgl. Dowie, 1901:224-228) en dit sou ook die klem van sy latere bediening in Suid-Afrika wees. Hy verhuis gedurende 1904 na Chicago en bring later in 1908 'n sendinggeselskap na Suid-Afrika. Tom Hesmalhalch was deel van die groep. Lake tree van 1910 op as predikant van die AGS van SA voordat hy in 1913 na die VSA terugkeer. Hy sal, soos reeds genoem, veral onthou word as 'n man wat sterk klem op goddelike genesing gelê het. Hy het baie oor dié tema onderrig gegee en reekse Bybeltekse as bewyse vir sy oortuiging aangevoer (vgl. Lake, s.a.).

Lake self meen dat die belangrikste Suid-Afrikaner in die beginjare van die AGS 'n gewese predikant van die Nederduits Gereformeerde Kerk, ene R. H. van de Wall was. $\mathrm{Hy}$ is egter jonk oorlede en het sodoende min werklike invloed uitgeoefen (vgl. Burger, 1987:182-193). Soos reeds vermeld, kom Lake se grootste vorming uit sy Amerikaanse verbintenisse. Sterk klem is op die werking van die Heilige Gees gelê, 'n ingesteldheid wat die moontlikheid skep om Skrifwarhede te ontdek en te beleef. Die Heilige Gees is nodig vir die "... power to preach the Word" en vir "... the deep revelations of 
wondrous truth" (Lake, 1911:2). Verder sê Lake (1911:3) "... I personally praise God for the wonderful and blessed truths of His word by the Spirit, revelations in doctrine, in prophecy, in poems ....". In 'n artikel met 'n sterk vermanende element, waarskynlik uit die pen van Lake, spreek hy egter mense aan wat die vryheid van die Gees ("to be led of the Spirit alone") so op die spits dryf dat daar geen ruimte is vir enige gesag (kerklik en staatkundig) of ruimte vir orde of leierskap nie (Lake, 1911:1). Hy sê van diegene wat hulle nuut ontdekte vryheid misbruik het, dat

... little attention was paid to the directions for control and government of mectings as provided in the Word of God ... Much of the confusion that has attended Pentecostal work has been caused by this failure to recognise proper government and authority in the Church as set forth in the Word of God (my kursivering - WJW).

Die gesag wat aan die Bybel toegeken word, spreek duidelik uit bogenoemde aanhalings. Vryheid van die Gees beteken dus nie vryheid en losmaking van die Woord van God nie.

Die volgende aanhaling (my kursivering - WJW)) kom uit 'n skrywe van Lake (1922) aangaande die waarheid van die Bybel. Hierin word duidelik geillustreer dat waarheid en die ervaring daarvan in direkte verband staan, soos vroeër reeds betoog.

I wonder if you have ever paid altention to the different occasions in reading the Scriptures when the VOICE OF (FOD is mentioned. You know the thing that makes the Bible the Bible is the fact that somebody had an interview with God. Somebody heard from heaven before there was any Bible. Then the conversation or the incident was recorded, and these became the Word of God. Now the Word of God is indestructible because it was a real voice, because it was a real experience, because (iod really did or said somcthing and the record thereof is true.

If you wanted to prove, like you do in mathematics, concerning the Bible and its inspiration it is very simple. Every child is taught to prove whether his sum is correct or not. And if you have doubts and questions and fears concerning the Bible and its inspiration, we know that if one soul ever heard from heaven another soul may. If ever one soul had an interview with God, another soul may. If any man ever knew his sins forgiven at any period another man may know his sins forgiven now. If there ever was a man or woman healed by the power of God at any time, then men and women can he healed again. And the only thing necessary is to refum again in soul experience to that same place of intimacy with God where the original individual met God. Now is that clear?

That is the way you prove the Word of God. That is the reason that Christians love the Word of God. That is the rcason that the Word of God becomes the thing that men live by and that men will dic by. The Word of God becomes a present living reality to them - not just as a theory. (Lakc, 1922:23.)

Vanaf 1908 tot 1913 het buitelanders soos Hesmalhalch en Lake die leiding in die AGS van SA geneem en grootliks die rigting bepaal en gebruike gevestig wat nó by soortgelyke bewegings in Amerika en Europa aangesluit het. Weldra, met die leierskap van P.L. le Roux, sou die kerk meer verinheems sonder om aksente soos Goddelike genesing en doop in die Heilige Gees te verwaarloos.

Dit wil voorkom of die pinkstergelowiges in Suid- Afrika se godsdiensbelewing en hul omgang met die Bybel, vanuit verskeie bewegings uit die buiteland beïnvloed is (vgl. 
onder andere Williams, 1974:5). Sake soos bekering, doop met die Heilige Gees en genesing (dus ervaring) is as Skrifwaarhede ontdek en beleef, maar daar was min besinning oor die aard van die Bybel. Die veronderstelling was dat die Bybel die Woord van God, en derhalwe gesagvol, is. Buiten die buitelandse invloede was daar egter ook inheemse gebeure en persone wat in hierdie Skrifbeskouing ' $n$ rol gespeel het.

\section{BELANGRIKE INHEEMSE GEBEURE EN PERSONE}

Binne pinkstergeledere word plaaslike herlewingsgebeure in die Nederduits Gereformeerde Kerk rondom 1860, as voorbereidend ervaar vir die ontstaan van die AGS van SA. Sowel Van der Spuy (1985:50-52) en Burger (1987:96-108) is van mening dat Andrew Murray groot invloed op persone in die AGS uitgeoefen het.

\subsection{A. Murray en P.L. le Roux}

Murray word nie alleen nó met bogenoemde herlewings na 1860 verbind nie, maar sy kontak met die Heiligheidsbeweging en die Keswickkonferensie is van belang. Murray se prediking, maar veral sy boeke rakende verskeie onderwerpe (in besonder dié oor die Heilige Gees en genesing) is wyd gelees en gewaardeer. Murray se gebruik van die Bybel om waarhede oor veral genesing en die werking van die Heilige Gees te beklemtoon, was vir die pinkstermense baie aanvaarbaar. Dit is in dié geval weer eens duidelik dat korrelasie tussen die Bybelse waarhede en die ervaring daarvan in die huidige omstandighede, die aanvaarbare norm was. Om dié rede het die pinkstergelowiges aanklank by Murray se benadering gevind .

Murray het meer direkte invloed op die AGS uitgeoefen in die persoon van P.L. le Roux wat die eerste inheemse leier van die AGS sou word (1913-1943). As seun het hy in die Wellingtondistrik opgegroei en was as kind reeds in Andrew Murray se gemeente. Hy bekwaam hom as onderwyser en hou in Wellington skool. Later studeer hy onder invloed van Murray aan die Sendinginstituut in Wellington en word sendeling van die Nederduits Gereformeerde Kerk te Wakkerstroom. Hy werk later vir 'n tydperk van twee jaar onder die Zoeloes in Greytown, maar keer weer na Wakkerstroom terug. Andrew Murray het sy bevestiging as sendeling in Wakkerstroom waargeneem. Dit is duidelik dat daar 'n hegte verhouding tussen hulle was en dat Murray ' $n$ groot invloed op Le Roux gehad het en dat hy bygedra het tot sy vorming (Burger, 1987:219).

Wat Skrifgebruik betref, het Murray sekerlik die grootste invloed op Le Roux uitgeoefen het. "He frequently quoted the late Dr Andrew Murray" (Opperman, 1943:19), terwyl sowel Murray as die Sioniste sy belangstelling vir die saak van Goddelike genesing wakker gemaak het. Van Le Roux word gesê: "He imbibed Dr Andrew Murray's Scriptural teaching on Divine Healing" (Comforter, 1910:2). Dieselfde artikel beskryf hom as 'n "... conscientious interpreter of God's Everlasting Truth ..." en sy tipe prediking as "... preaching with signs following ...". 
Murray het dus op indirekte wyse deur sy prediking en boeke, maar ook op 'n meer direkte wyse deur P.L. le Roux sy invloed in die AGS gevestig. Dit is eweneens duidelik dat die aanvaarding van die gesag van die Skrif en die abstrahering van waarhede wat daarin vervat is en prakties beleefbaar is, Murray se Skrifgebruik vir die pinkstermense aanvaarbaar gemaak het.

Buiten die noue kontak met Andrew Murray, het die Sionisme in Suid-Afrika'n sterk invloed op P.L. le Roux uitgeoefen. In 'n stadium het hy met ene Johannes Büchler kennis gemaak, 'n piëtis wat in 1895 'n eie gemeente onder die kleurlinge vestig. Büchler is deur Dowie beïnvloed en het 'n genesingskliniek in Jeppe begin. Sy weë het egter gou van Dowie geskei. Büchler het egter sy vriend P.L. le Roux aan Dowie se nuusblaadjie oor Goddelike genesing bekendgestel, iets wat besonderse belangsteling by Le Roux gaande gemaak het.

Le Roux kom deur middel van ene Daniël Bryant, 'n volgeling van Dowie, in noue kontak met die Sioniste. In 1903 bedank hy uit die Nederduits Gereformeerde Kerk en sluit by die Sioniste aan. In 1904 word hy deur Bryant deur middel van onderdompeling gedoop. In 1908 sluit Le Roux in Johannesburg by die Lake-geselskap aan wat pas as sendelinge uit die VSA in Suid-Afrika aangekom het en in 1913 word hy as president van die AGS verkies. Deur sy kontak met Lake, wat op 'n stadium noue bande met Dowie gehad het, kom Le Roux opnuut in aanraking met invloede uit die Sionisme. Van Le Roux sê Burger (1987:116): "Daar kan aanvaar word dat sy teologiese en leerstellige oortuigings tot ' $n$ groot mate ' $n$ integrasie was van wat hy by Andrew Murray geleer het en die oortuigings waartoe hy by die Sioniste gekom het." Hy word in die pinkstergeledere as 'n gebalanseerde en Skrifgebonde persoon beskou.

Le Roux het van die standpunt uitgegaan dat die Bybel ewige waarhede bevat, wat, soos in die tyd van die Apostels, opnuut beleef kan word, soos ook die volgende illustreer:

... door op zijn volk de "Spade Regen" te doen neerdalen met de tekenen en wonderen van het eerste Apostoliese tijdperk. Hij is niet veranderd ... Zijn Woord is niet veranderd. Zijne beloften zijn ja, en zijn amen. Laat ons terug gaan naar Gods Woord, terug na Jezus Christus, de Zoon van God ... terug naar die Pinksteren van Hand 2, en wij zullen niet langer behoeven vragen of tekenen en wonderen slechts voor enige jaren, dan of zij voor al die eeuwen bedoeld waren (Le Roux, 1921:4).

Hoewel die klem in die Pinksterbeweging sterk op die leiding van die Heilige Gees was, was die uitgangspunt wat van P.L. le Roux as pastoor (toe nog genoem broer) van die AGS dat daar balans moet wees. In 'n berig oor 'n besoek van ene Donald Gee uit Engeland in 1932, verwys Le Roux na 'n toespraak van Gee waarin hy na aanleiding van twee Bybelverse, Efesiërs 5:18-19 en Kolossense 3:16, balans bepleit.

Hy sè dat hy genoem word die Aposiel van Balans. Daar is mense wat net tale en profesie wil hê, ander weer wil net die Woord he. Ons het beide nodig as ons wil beantwoord aan die doel waartoe God ons geroep hel (Le Roux, 1934:9). 
Uit bogenoemde aanhaling is dit duidelik dat Le Roux hierdie mening met Gee deel. In dieselfde jaar skryf ene Morgan oor God se leiding en meen dat alle leiding van die Heilige Gees in harmonie met die Bybel moet wees. Egte leiding is nie in teëspraak met die Bybel nie (Morgan, 1934:20).

Dit is voorts ook duidelik dat die Bybel vir Le Roux die maatstaf van leer en lewe was. In 'n skrywe oor die straf van die goddelose sê hy: "As die Here ons in Sy Woord geen lig gee nie, dan moet ons tevrede wees om onkundig te bly. Maar ons meen dat die Skrif ons nie in die duister laat aangaande die saak nie" (Le Roux, 1936:30). Ooreenstemming in leer is vir hom belangrik, anders is daar nie eenheid in die gemeenskap nie en dit is nodig, "... as ons begeer dat Gods Gees onder ons tot volle openbaring sal kom..." (Le Roux, 1936:30). Die twee komponente van Woord en Gees was vir hom van kardinale belang en daar was nie teëspraak tussen die twee nie. Dit kan afgelei word dat daar vir Le Roux nie 'n spanning tussen die twee komponente bestaan het nie, maar wel 'n natuurlike, dinamiese verhouding (vgl. ook Gaede, 1989:81).

In 1936 skryf Le Roux dat geleerdheid sterk op die voorgrond tree en dat geleerde mense die Bybel as te eenvoudig ervaar. In sy reaksie sê hy:

Ons dank die Here vir die beweging wat vierkantig op Giods Woord staan, en alles aanneem wat die
Here gese het. Ja, die Pinkstergelowiges, gevul met die Heilige Gees, glo alles wat gesknwe staan.
Hulle neem aan wat Paulus verklaar: "Die hele Skrif is deur God ingegec"(2 Tim 3:16). Hulle
necm ook aan die verklarings van onse Here Jesus: "Dic Skrif kan nic gebreck word nie"(Joh
10:35), cn "Die hemel cn aarde sal verbygaan, maar my woorde sal nooil verbygatan nic" (Matt.
24:35). En omdat hulle dic woord aanncem en daarop vertrou, word die waarheid daarvan in
hulle ondervinding bevestig. Hulle kan sề "Ek weet dit is waar; nie net omdat dit in die Bybel
geskrywe is nic maar my eie ondeninding bevestig dir" (Le Roux, 1936:5; my kursivering - WJW).

Hierdie aanhaling bevestig net weer die waarneming dat die ontdekte waarhede van die Bybel in ervaring bevestig word. Sy eie woord is "... dat God se beloftes onwankelbaar waar is, en dat in onse dae, net sowel as in vorige eeue, die gelowiges kan reken op die vervulling van wat geskrywe staan" (Le Roux, 1936:5).

\subsubsection{Die era 1913-1943}

'n Mens sou seker dié era die P.L. le Roux-era kon noem, omdat dit die tydperk was waarin hy as die president van die AGS opgetree het. In die aanvangsjare was daar nie sprake van 'n professionele pastoraat nie en gelowiges is as gelyk geag en almal kon leer soos die Heilige Gees die Woord vir hulle ontsluit het (vgl. Langerman, 1983:82; Van der Spuy, 1985:68-69). Mettertyd het die behoefte aan sterker leiding ontstaan om wanpraktyke uit te skakel en verskille op te los. Die gewone gelowige het spontaan met die Bybel omgegaan en dit as gesagvol gerespekteer. Besware sou sekerlik ingebring kon word oor die wangebruik en die verkeerde gebruik (sonder inagneming van konteks en a-histories) van die Bybel (vgl. in hierdie verband die boek van Van Zijl Waarom ek "Die Wederdopers" verlaat het, 1925), maar die gewone lidmaat was lief vir die Bybel en het hulle lewens daarvolgens probeer inrig. Van Zijl self erken dat die raad van die Wederdopers om die Skrif self te ondersoek, goeie raad was: 
En ek moet sê, ofskoon ek baie jare lank 'n Bybellescr was, het ek nooit soveel ontdek as gedurende die tyd toe ck met die Wederdopers saamgestaan het nie. Nou ook nog, wanneer ek selfs in die holte van dic nag die groot waarhede van (rod bepeins, word dinge vir my meer en mecr duidelik (Van Zijl, 1925:12).

Die vroeë gelowiges in die AGS was arm en eenvoudig en uitgesproke teen veral teologiese kennis. Van die redes wat voorgehou was, was onder andere die skerpe veroordeling en dikwels ongegronde beskuldigings van die geleerde predikante van die Afrikaanse kerke. Hulle ervaring was ook dat die kragtige, maar eenvoudige verkondiging van die Woord deur lekepredikers, dikwels met tekens en wonders bevestig is. Verder het 1 Korintiërs 2:1-6' $n$ invloed op hulle beskouings uitgeoefen en daar is geglo dat die letter doodmaak, maar die Gees lewend maak (vgl. Le Roux, 1928:3; Van der Spuy, 1985:107). Hulle het in hulle eenvoud en met groot ywer die Bybel gelees en bepeins met die oog daarop om 'geestelike' mense te wees.

Die letterlike en ooglopende waarheid van die Bybel is kritiekloos aanvaar. Ene W.F. Dugmore waarsku teen 'de Nieuwe Theologie' waarby sommige predikante betrokke geraak het wat daartoe gelei het dat hulle die waarheid van God se Woord in twyfel trek. Sy (Dugmore, 1921:1-2) standpunt is:

In alle nederigheid zijn wij bereid te alle tijd de waarheid, dic wij verkondigen, uit Gods Woord se bewijzen. Wij rijn bereid met open Bijbel clkeen te ontmocten, dic naar licht zockt en met zachtmoedigheid de legenstanders te onderwijzen. (My kursivering - WJW.)

Vir die pinksterlidmaat kon die waarhede wat hulle aangehang het, uit die Bybel bewys word. Die Bybel het die hoogste gesag gehad (vgl. Van der Berg, 1937:7). In 1938 volg op versoek van lidmate 'n uiteensetting oor wie die AGS nou eintlik is en wat hulle glo en leer. Oor die Bybel word gesê: "Ons glo in die ingewing van die Skrifte as die openbaring van Gods gedagte en wil. Die Bybel is die geinspireerde Woord van God. en daarby 'n onfeilbare reël van geloof en gedrag en hoër as ons gewete en verstand" (2 Tim. 3:15-19, 1 Pet. 2:25, 2 Pet. 1:19-21; Heb. 4:12, Matt. 5:17-18) (Trooster, 1938:10; vgl. vir 'n soortgelyke verklaring oor die Bybel waarby ingevoeg is "... die onfeilbare algenoegsame, reël vir ons geloof" - Comforter, 1941:3).

Die sterk oortuiging dat die Bybel die waarheid bevat waarvolgens 'n mens jou lewe moes inrig, het soms ernstige gevolge meegebring. Die weiering van mediese behandeling en medisyne is ' $n$ goeie voorbeeld hiervan (rondom militêre diens was byna ' $n$ soortgelyke standpunt weens Skrifoortuiging; Burger, 1987:269-73). Met betrekking tot die houding aangaande mediese hulp het Le Roux self sterk leiding geneem. Hy reageer in 1918 by 'n konferensie van die AGS soos volg: "Br P.L. le Roux asked how God heals. Does he institute Doctors and tell us to go to them? No. Ex 15:26 - He says 'I am the Lord your Healer'” (vgl. Burger, 1987:242). Vir die saak was persone bereid om risiko's te loop, hofsake te verduur en die regering te nader vir kwytskelding van wetlike vervolging. 
As the responsible leaders we exhort our people to be true to their principles and faithful to God and His Word. We further declare it to be our determination to obey God rather than man as did the Apostles of old. If we have to suffer for conscience sake and for the Gospel we are willing to do so (Burger, 1987:245).

Hulle standpunt oor die aangeleentheid was op teksgedeeltes soos Markus 16:18 en Jakobus 5:14-16 gegrond. Die letterlike verstaan van die Bybel as Woord van God is met erns bejeën en hulle was bereid om baie vir hulle oortuigings te verduur. Hierdie amptelike standpunt oor mediese aangeleenthede is vir die eerste veertig jaar van die AGS se bestaan gehuldig (vgl. die Memorandum van die AGS voorgelê aan die Kommissie van die Nasionale Gesondheidsdienste in Oktober 1943). In die vyftigerjare, met 'n tweede geslag volgelinge, is dié standpunt laat vaar en is anders oor die aangeleentheid gedink (vgl. Burger, 1987:247-248). In 'n nie-amptelike memorandum deur J.T. du Plessis (1956:3) onderskei hy tussen mediese genesing en Goddelike genesing, en meen hy dat hy sodoende steeds dieselfde Skrifgebruik kan handhaaf. In die memorandum spreek hy hom positief uit teenoor die mediese wetenskap en bedank hy die owerheid wat die gesondheid van die bevolking wil bevorder. Hy doen egter 'n beroep op die gelowiges om hulle vir die genadedaad van God se genesing te beywer. Dit was egter, soos reeds tevore vermeld, die ervaring van genesing wat bevestig het dat die waarheid van die Woord van God in die huidige tyd nog net so geld as in Bybeltye.

\subsubsection{Formele onderrig}

Binne die geledere van die AGS is tydens die Le Roux-era 'n leemte aan leiers met grondige Bybelkennis ervaar. Van tyd tot tyd het stemme opgegaan vir Bybellesings en opleiding (vgl. Le Roux, 1936:30). Die Bybelgebruik was oorwegend in die hande van die gelowige en leke-predikers, met enkele uitsonderings soos Le Roux en andere wat oor teologiese opleiding beskik het.

Reeds in 1920 was daar by die AGS van SA blyke van 'n behoefte aan een of ander vorm van onderrig in die Bybel. By die konferensie vir werkers (WK) in Bloemfontein in Augustus 1920, is besluit dat 'n skool vir opleiding van jongmense in Kaapstad tot stand moes kom. Dit sou 'n skool wees om jongmense as sendelinge voor te berei en sou oop wees vir "... allen, die met de Pinkster Beweging mee gingen" (Trooster, 1921:11). Dit is egter duidelik beklemtoon dat dit nie ' $n$ teologiese inrigting sou wees soos dié van ander kerke nie, maar 'n plek waar jongmense en ander opgelei kon word om die Woord van God reg te verstaan (Notule WK, 1920). Later sou dit blyk dat die AGS nie direkte beheer oor die skool gehad het nie, maar dat ene S. Moffat dit interkerklik aangebied het (Notule WK, 1921). Lake het na hom verwys as ' $n$ "Wesleyan Methodist Local Preacher" (Burger, 1987:234).

In 1926 het daar weer 'n byeenkoms vir werkers plaasgevind waar die behoefte aan 'n opleidingskool opnuut na vore gekom het. As rede is aangevoer die behoefte aan beter beheer oor gemeentes (Notule WK, 1926). 'n Sterk oproep vir finansiële steun 
om 'n Bybelskool tot stand te bring, volg in 1928 deur die president van die AGS, P.L. le Roux. Hy het gesề (Le Roux, 1928:3):

Gods Gees maak bekwaam om die Woord te verstaan. Maar moenie denk dat as iemand die Heilige Gees ontvang het, dat hy dan maar dadelik alles verstaan en aan ander gaan leer wat in die Woord is nie.

Hy beklemtoon dat 'n evangeliedienaar kennis van die Woord nodig het, want dwaling skuif in waar kennis ontbreek of gebrekkig is. Hy wys daarop dat gemeentes in Ameri$k a$ reeds aan so 'n behoefte in hulle geledere beantwoord het (Trooster, 1921:3-4). ' $n$ Bybelskool met ' $n$ kursus wat drie jaar sou duur, is vir September 1930 in Johannesburg in die vooruitsig gestel (Trooster, 1930:10). Die leerplan van die kursus het 'n groei in besinning oor die Bybel en verwante sake getoon.

Die Bybelskool realiseer egter eers in Februarie 1931 met ene Henrietta Fruen in beheer (Comforter, 1931:9, WK Verslag 1930:2). 'n Jaar later sluit die Uitvoerende Raad van die AGS die skool na 'n verskilpunt met Fruen (Langerman, 1983:96). Hierna is belangstelling getoon in die opleiding van die Berean Bybelskool van die 'Assemblies of God' onder beheer van ene C. Bennet (Trooster, 1934:6).

Die hele kwessie van 'n Bybelskool is weer by die Werkerskonferensie van 1936 ter sprake gebring en intens gedebatteer. Sommige sprekers het sterk klem gelê op die verwerwing van Bybelkennis, terwyl ander weer klem gelê het op die praktiese sy van die bediening. Sprekers het veral daarop aangedring dat die klem moet val op 'n 'Heilige Gees-bediening' eerder as 'n 'geleerde bediening'. Uiteindelik is besluit dat die tyd om 'n Bybelskool te begin nie ryp was nie. 'n Besluit is geneem om rondreisende 'dosente' na gemeentes te stuur. Van formele teologiese opleiding was tot in dié stadium geen sprake nie.

Behoefte aan opleiding vir werkers het toegeneem en op 12 April 1939 is besluit om 'n sentrum vir opleiding op te rig. Bennet, soos reeds genoem, is op 20 Februarie 1940 as die prinsipaal van die Bybelskool aangewys en 'n huis in Belleve, Johannesburg is vir dié doel bekom. Die Bybelskool is amptelik op 9 Junie 1940 geopen. Sterk klem is op die praktiese sy van die opleiding gelê. Hoewel die opleiding sterk aanbeveel is vir voornemende predikers, was dit nie verpligtend nie (Van der Spuy, 1985:142). Hierdie poging tot opleiding het ook soos voriges na 'n paar jaar ten einde geloop.

\subsubsection{Samevatting}

$\mathrm{Na}$ 'n aanvanklike eenvoudige en ongekompliseerde omgang met die Bybel, vind daar mettertyd kerklike, maar ook maatskaplike veranderings plaas. 'n Behoefte aan opleiding vir voorgangers en 'n verbetering van formele kennis van die Bybel het ontstaan. Hierdie behoefte het in die hand gewerk dat besin is oor die aard, wese en gebruik van die Bybel, hoewel op 'n baie beperkte skaal. Die Bybel is steeds op die ongekompliseerde en direkte wyse deur die pinkstergelowiges gebruik en ruim vryheid 
is gelaat dat die Heilige Gees die verligting kon bewerk om die Bybel te verstaan en toe te pas. Le Roux self het die beweging vir bykans dertig jaar met sy gebalanseerde opvattings oor die Bybel en die Heilige Gees gelei. Werklike teologiese nadenke oor die Bybel het op beperkte skaal plaasgevind. Terwyl Lake slegs die buitelandse invloed in die AGS ingedra het, het daar met Le Roux se leierskap ook inheemse invloede (o.a. Murray) in die spel gekom.

\subsection{Die tydperk 1944 en verder}

Verandering het in die AGS ingetree, veral in die periode van 1944-1958. Die leierskap het verander, beskouings oor 'kerkwees' het verander, lidmate en predikers het sosiaal in die samelewing betrokke geraak, die liturgie het verander en kontak is met ander kerkgenootskappe gemaak (vgl. Burger, 1987:297-317). Spanning het ook rondom die sang en die musiek in die kerk ontstaan weens veranderinge wat ingetree het (vgl. Van der Spuy, 1985:147-151).

Die algemene lewenstandaard van die lidmate van die AGS, asook die verbetering van opvoedkundige kwalifikasies van lidmate, het grootliks tot hierdic veranderinge bygedra. Tog moet daar gesê word dat dieselfde basiese oortuigings van die mense in die Pinksterbeweging nie verander het nie, maar die intellektuele en kuiturele ontwikkeling by die lidmate het die verfyning van beredenering teweeggebring. Die Bybel is steeds as die belangrikste bron van lewe beskou en die Woord van die Here is steeds met ywer ondersoek vir elke dag se bestaan. Van die predikers met meer ontwikkelde intellek het hulle daarop toegelè om Skrifwaarhede in meer sistematiese en beter gestruktureerde uiteensettings op skrif aan te bied (vgl. Gillingham, 1952:1-4). Intussen het die AGS 'n Geestelike Komitee op die been gebring wat uitspraak moes gee oor kontensieuse sake. So 'n uitspraak met uitvoerige Skriftuurplase daarby, is bywoorbeeld 'n verslag oor die hou van Wagdienste rondom Pinkstertyd (vgl. Verslag, 1953:2-3). Die AGS het in die proses van kerkwording en ontwikkeling van die lidmate en die pastore meer gesofistikeerd geraak, sonder om werklik hul Skrifopvatting te wysig.

Sosiale omstandighede soos politiek, kontak met ander kerke en die bchoefte om deur middel van die SAUK kerkdienste uit te saai, het die AGS gekonfronteer met nuwe vraagstukke. Hierdie vraagstukke behels onder andere lidmate se betrokkenheid by partypolitiek, eie belydenisskrifte, liturgiese veranderinge en teologiese opleiding.

\subsubsection{Politieke betrokkenheid}

Vir bykans die eerste vyftig jaar van sy bestaan was die kerk geensins by politiek betrokke nie en is dit as 'n private aangeleentheid van elke lidmaat beskou. Vir 'n groot deel van sy wordingsgeskiedenis was die AGS meer Engelsgesind (a.g.v. Amerikaanse bande) as die ander Afrikaanse kerke. Die Nasionale Party se oorwinning in 1948 het groot invloed op die AGS uitgeoefen, aangesien daar 'n groot aantal lidmate was, wel swygend, wat lede van die Verenigde Party was. 'n Sluimerende anti-Na- 
sionale Party en anti-susterkerke-gevoel het hand aan hand gegaan (vgl. die baie predikante in die politiek, bv. dr. D.F. Malan; Burger, 1987:325). Die kwessie is egter op die spits gedryf met G.R. Wessels, die destydse visepresident van die AGS wat partypolities betrokke geraak het en in 1955 as senator verkies is. Baie lidmate was van mening dat hy die kansel misbruik het vir Nasionale Party-propaganda. Die Geestelike Komitee van die AGS was genoodsaak om uitspraak oor die aangeleentheid te gee en soos dit die gebruik was, moes dit 'n Skriftuurlike uitsluitsel wees. Twee belangrike grepe uit die verslag ter illustrasie:

Volgens Rom. 13:1-7 is burgerlike en regeringsoutoriteit deur God georden, derhalwe moet staatsake en die uitvoer daarvan nie noodwendig as onheilig beskou word nie, alhoewel sulke elemente daarin kan voorkom.

Volgens 2 Tim 2:4 moet die voltydwerker sy tyd en kragte wy aan die uitbreiding van God se Koninkryk en hy kan derhalwe slegs op ' $n$ raad of enige ander liggaam dien mits

(a) sy posisie daar, daarop neerkom dat hy as vertecnwoordiger van die kerk optrec, en

(b) hy sy rocping daar uitleef, volgens die eise wal van 'n voltydwerker verwag word. (Verslag Geestelike Komitce, 1956.)

In 'n referaat wat by 'n Werkerskonferensie gelewer is met die titel "Partypolitiek of Pinkster Homiletiek", gee J.H. Snyman ('n pastoor van die AGS) sterk uitdrukking aan" sy teenkanting teen die politieke betrokkenheid van 'n voltydwerker. Vir elke argument wat hy gevoer het, het Snyman teksverse ter ondersteuning daarvan aangehaal. 'n Enkele aanhaling illustreer dit duidelik. "In Galate 5:19-21 noem die Apostel Paulus die werke van die vlees en dit is dieselfde eienskappe wat in die partypolitiek voorkom" (Snyman, 1956:2). Hierby voeg hy nog Lukas 6:43,44. Uit die referaat is Snyman se standpunt baie duidelik asook sy eie politieke simpatie: om dit te legitimeer, gebruik hy die Bybel konteksloos en sonder aanduiding van enige historiese bewussyn. Op interessante en selfs verbeeldingryke wyse vleg hy argument en teksbewyse deurmekaar (vgl. Snyman, 1956:1-10). Snyman het ook gereageer op die uitspraak van die Geestelike Komitee en konkludeer "Die Skrif sê nee, die Geestelike komitee sê nee ..." (Snyman 1956:9). Hierdie laaste 'nee' is duidelik sy eie interpretasie van die uitspraak.

Uit die hele bespreking het dit duidelik geblyk dat die Bybel steeds as norm aangewend is, maar ook dat die toepassing en uitleg nie gevrywaar was van eie oortuiging van sake nie. Met die toename in die ontwikkelingspeil van die lidmate het daar, onbewustelik miskien, ander elemente in die spel van Skrifuitleg gekom.

\subsubsection{Liturgiese verskuiwinge}

Die ontwikkeling tot beter organisasie, kerkwees en sosiale blootstelling het liturgiese veranderinge in die hand gewerk. Preekstoele in plaas van tafels het in gebruik gekom, kerke is opgerig en kerkmusiek het ook onder bespreking gekom. Sommige persone het ' $n$ behoefte aan groter orde in eredienste en aanbidding gehad en daar was selfs diegene wat die Geloofsbelydenis wou voorlees. Snyman (1955:1-4) het in opposisie weer hierin die leiding geneem en op dieselfde wyse as met die politieke betrokkenheid, vers na vers aangehaal om sy standpunt tuis te bring. Die kerk moes op hulle 
beurt ook amptelik sê wat die Bybel sê. In 'n ondersoek deur die Geestelike Komitee na handeklap, bevind hulle dat dit nie 'n leerstellige saak of 'n voorskrif is wat op Bybelgronde berus nie. Volgens hulle opvatting is Psalm 47:2 digterlike taal, so ook Psalm 18:30, 73:9, 98:8 en 114:5-8 (Verslag Geestelike Komitee, 1955). 'n Interessante ontwikkeling kan hier waargeneem word deurdat ander elemente betrek word in die verklaring waarom Psalm 47:2 nie van toepassing sou wees nie. Hiervolgens moet digterlike taal dus nie letterlik opgeneem word nie. Gaandeweg het 'n aanvoeling ontwikkel dat die verstaan van die Bybel meer as net bloot lees en toepas verg. Wessels (1955:13) skryf in dié verband: "Tog is dit so noodsaaklik dat ons iemand sal hê wat behoorlik in die klassieke tale onderleg is om ons predikers te leer." Grieks en Hebreeus het noodsaaklik geblyk, want die eksegese stel bepaald groter eise vir die tyd waarin hulle hul bevind het. Die AGS leiers wou dat die kerk homself handhaaf in die samelewing met sy gereformeerde kerke en geleerde predikante.

\subsubsection{Belydenisskrifte}

Daar is reeds na enkele nie-amptelike leerstellige verklarings verwys wat uit vroeër jare dateer (vgl. Trooster, 1938:10; Comforter, 1941:3). Die AGS het egter vir jare sonder formele belydenisgeskrifte voortgegaan, omdat die gevoel bestaan het dat die Bybel die basis van hulle geloof was. Dit is te begrype aangesien die Bybel in die hande van die gewone gelowige was en 'n professionele pastoraat eers in die dertigerjare beslag gekry het. Hiermee saam het formele opleiding, soos later sal blyk, eers werklik in die vyftigerjare beslag gekry. Intussen het, soos aangedui, die sosiaalmaatskaplike betrokkenheid van die lidmate en die behoefte aan SAUK-uitsendings, die AGS genoodsaak om aan belydenisskrifte aandag te gee. In 1950 kry F.P. Möller opdrag om sodanige verklaring van geloof te formuleer en in 1957 word die belydenisskrifte aanvaar (vgl. Van der Spuy, 1985:158). In die voorwoord by die belydenisskrifte word gestel dat die Apostoliese Geloofsbelydenis, die Geloofsbelydenis van Nicéa en die Geloofsbelydenis van Athanasius onderskryf word; verder ook die Nederlandse geloofsbelydenis insoverre dit as Skriftuurlik beskou word. Enkele wysigings is aangebring aan sommige artikels van die Nederlandse geloofsbelydenis, naamlik artikels $15,16,25,33,34$ en 37 en 'n artikel $11 \mathrm{~b}$ is bygevoeg om die Pinksterstandpunt duidelik te stel. Die oortuiging is uitgespreek dat die wysigings "... in die lig van die Bybel" genoodsaak was (Belydenisskrifte, 1957:4). Die artikels waarby veranderings aangebring is, handel oor erfsonde, (uit)verkiesing, die Wet, sakramente, die doop en die laaste dinge. Al die artikels wat oor die Woord van God (Heilige Skrif) handel, is dus ongewysig deur die AGS onderskryf (artikels 3-7).

\subsubsection{Kerkskeuring en nuwe inisiaticf}

In 1958 het die AGS 'n skeuring beleef toe die Pinkster Protestante Kerk weggebreek het. Verskeie faktore is as redes genoem waarom dié skeuring plaasgevind het: hieronder geld die politieke betrokkenheid van onder andere G.R. Wessels, die woelinge rondom liturgiese verskille soos handeklap en 'lewendiger' dienste, asook die opskrifstelling van die kerk se belydenis. Een van die wegbrekers het leerstellige verskille 
gehad oor die vertolking van Johannes 3:5 waarop die AGS gereageer het dat doopswedergeboorte as dwaalleer verwerp word (vgl. Burger, 1987:339).

Dit is duidelik dat groot verskuiwings en ontwikkelings plaasgevind het, nie noodwendig in die algemene gebruik van die Bybel nie, maar in kerkwording. In die proses het die AGS strukture ontwikkel wat voortaan uitsluitsel oor kontensieuse sake sou gee en het die besluitneming verskuif vanaf die lidmaat na die kerk as organisme.

Die eerste werklik formeel-geleerde of teoloog van die AGS, F.P. Möller, het in die vyftigerjare sterk op die voorgrond begin tree en voortaan sou hy met sy boeke en verslae grootliks die toon aangee. In 1955 verskyn sy boek Ons Pinkstererfenis waarin hy uitvoerig die hele saak van pinkster uiteensit - soos dit deur die tradisie waarin hy staan, verstaan word. Sake wat grootliks in die harte van gelowiges geleef het, is nou op skrif gestel - 'n feit wat onwillekeurig formalisering in die hand gewerk het. In 'n groot mate het Möller die Skrifgebruik soos bekend in die AGS voortgesit, egter net op 'n baie meer gesofistikeerde wyse as enige van sy voorgangers. Terwyl die ondervinding of ervaring steeds beklemtoon is, is die bewysvoeringskant vanuit die Bybel as norm en gesag, sterker beklemtoon.

\subsubsection{Teologiese opleiding in die AGS van SA}

Daar is reeds by die gedeelte oor P.L. le Roux gewys op die aanloop en ontwikkeling van opleiding gedurende sy tyd van leierskap. 'n Ontwikkelende kerk kon nie daarvan wegkom om aandag te gee aan die skoling van leiers wat as voorgangers van gemeentes moes optree nie. 'n Sogenaamde Suid-Afrikaanse Bybelkollege het in 1946 'n korrespondensiekursus in homiletiek aangebied (Trooster, 1946:24). Op 23 September 1949 is 'n volledige korrespondensiekursus ingestel, asook 'n beheerkomitee (Langerman, 1983:97). Waar tevore gepraat is van 'n Bybelskool wat mense moes toerus in Bybelkennis, is nou verwys na 'n Bybelkollege met as taak onder andere "... om ons leerstelling duidelik te formuleer en op skrif te stel ..." (Comforter, 1950:15). Die toerusting wat vir 'voltydwerkers' beoog is sou Grieks en Hebreeus insluit (Comforter, Februarie 1950:15).

Op 2 Februarie 1954 heropen die binnemuurse kollege en begin die eerste studente met 'n kursus wat twee jaar teoretiese en een jaar praktiese opleiding sou behels (Trooster, 1954:8). In 1954 word 'n besluit aanvaar dat applikante vir voltyddiens (behalwe in spesiale gevalle) voortaan verpligte Bybelskoolopleiding moes ondergaan (Notule Werkersraad (WR), 1954). Opleiding is of deur twee jaar binnemuurse opleiding ontvang. of deur middel van 'n agtvakkorrespondensiekursus. In 1958 is matrikulasie as vereiste gestel vir die ordening van leraars (Van der Spuy, 1985:143).

Mettertyd het pastore begin besef dat hulle beter toegerus moet wees vir hulle taak, maar daar het ook 'n bewussyn van 'n eie identiteit van kerkwees binne die kerklike toneel in Suid-Afrika ontwikkel. In 'n brief in 1964 skryf pastoor J.T. du Plessis soos 
volg: "Ons poog om die akademiese en teologiese kwalifikasies van ons pastore gelykwaardig met die gereformeerde kerke se predikante te kry" (Du Plessis, 1964:1). Goeie opleiding was een van die faktore wat as noodsaaklik beskou was vir die AGS om aanvaarbaar te wees vir die ander kerke in Suid-Afrika. Om maar een voorbeeld te noem - die AGS het 'n lang opdraande pad geloop om toegelaat te word om te kon deel in uitsaaidienste by die SAUK. Onder andere is vereis dat die belydenisskrifte op die tafel geplaas moes word en ook hoedanig die opleiding van pastore is (vgl. Van der Spuy, 1985:190-191; Du Plessis, 1982:1-4).

Geleerdheid was en sal nooit die grootste ideaal van die AGS wees nie. Die proses wat deurloop is tot die bereiking van die huidige standaard van opleiding, het met moeite gepaard gegaan. Met kerkwording en die ontwikkeling van 'n eie identiteit het selfvertroue gegroei en het daarmee saam het die sterk reaksie teen geleerdheid ook in 'n mate afgeneem. Wat in Pinksterkerke in die buiteland plaasgevind het, was belangrik vir die AGS (Trooster, 1953:8), maar van groter belang was die feit dat die AGS in die samelewing in Suid-Afrika 'n belangrike rol begin speel het - 'n feit wat genoodsaak het dat die kerk na eie posisie en handhawing naas ander kerke moes omsien. In dié opsig sou teologiese opleiding 'n belangrike funksie vervul.

\section{GEVOLGTREKKING}

Twee komponente het dwarsdeur die geskiedenis van die AGS belangrik gebly, naamlik die Woord van God en die ervaring van die Heilige Gees. 'n Spontane wisselwerking tussen die twee komponente het die eerste veertig jaar van die bestaan van die kerk geheers. Die waarhede van die Bybel is spontaan geglo en in ervaring beleef. Die ontwikkeling tot kerkwees met sterker organisasie en vaste strukture, sosiaalmaatskaplike betrokkenheid en intellektuele ontwikkeling, het tot gevolg gehad dat lidmate 'n meer kritiese ingesteldheid ontwikkel het. Die spontane geloofsbelewing het plek gemaak vir 'n minder naïewe aanvaar van gebeure, en die AGS was genoodsaak om strukture soos die Geestelike Komitee te skep om objektief oor sake te oordeel. Waar gelowiges vantevore die Bybel onkrities as gesagvol aanvaar het, het omstandighede sodanig ontwikkel dat die gesag van die Bybel meer geaksentueer is en betrek is by elke saak waaroor uitsluitsel gekry moes word. In die proses het gevolg dat die verhouding met die Bybel meer formeel geraak het en dat spanning soms ontstaan tussen die Bybel met sy gesag en die ervaring wat daaruit voortgevloei het. Hoewel albei komponente, Skrif en ervaring, bly voortbestaan het, het die spontane wisselwerking in die slag gebly.

Weens die verandering van die sosiale rol van die kerk naas ander kerke en die behoefte aan erkenning en selfhandhawing, moes die AGS noodgedwonge aandag gee aan die formulering van 'n eie identiteit en die daarstelling van 'n goeie opleidingstandaard. In die proses moes die kerk na kritiese stemme luister om steeds getrou te bly aan eienskappe wat as wesenlik beskou is. Indien die AGS die ervaringsmoment sou verloor, sou 'n wesenseienskap tot niet wees. 
Hoewel daar gepoog is om feite wat waargeneem is krities te evalueer en te interpreteer, kan 'n beskrywende studie soos hierdie grootliks net oorsigtelik en veralgemenend van aard wees. Dit sal meerdere pogings verg om die onderwerp in detail te bestudeer en veral die sewentiger- en tagtigerjare asook die huidige tydvak, sal indringender nagevors moet word.

\section{BIBLJOGRAFIE}

BELYDENISSKRIFTE 1957. Dic belydenisskrifte van dic Apostolicse Geloofsending van Suid-Afrika. Braamfontcin : Evangelic Uitgewers.

BURGER, I.S. v.d. M. 1987. Geloofsgeskiedenis van die Apostolies Geloofsending van Suid-Afrika, 19081958. Braamfontein : Evangelic Uitgewers.

COMFORTER. 1910. God Has a Controversy with the Church in Africa. p. 2. Od.

COMFORTER. 1931. The Bible Institute. p. 9. Jan.

COMFORTER. 1941. Leerstellings. p. 3. Nov./Des.

COMFORTER. 1950. Dic Apostolicse Bybel-Kollege. p. 15. Febr.

DOWIE, J.A. 1901. Leaves of Hcaling. God's Witnesses to Divine Healing.

DUGMORE, W.F. 1921. Het volle Evangelic. Trooster:1-2. Maart.

DU PLESSIS, J.T. 1956. Memorandum: Standpunte oor verskillende sake voorgelè aan die gemeentcraad van Krugersdorp. Kew, Johannesburg : AGS Argief. pp. 1-7.

DU PLESSIS, J.T. 19,4. Bricf van Past. J.T. du Plessis, Hoofsekretaris van dic AGS van SA. Okt. 5.

DU PLESSIS, J.T. 1982. Brief van Past. J.T. du Plessis, Hoofsekretaris van dic AGS van SA. pp. 1-4. Jan. 20.

DU PLESSIS, I.G.L. 1986. Die opkoms en groei van die Pentekostalisme in Suid-Afrika met besondere verwysing na die Volle Evangelic Kerk van God in Suidelike Afrika: 1910-1985. Pretoria. (Ongepublisecrde D.Th. procfskrif, Unisa.)

GAEDE, C.S. 1989. Glossolalia at Azura Sıreet: A Hidden Presupposition. Westminster Theological Joumal, 51(1):77-92.

GILLINGHAM, J.W. 1952. Dic Wagdicns (Opknappingskursus). Scplember. Ongepublisecrd.

INSTITUUT VIR REFORMATORIESE STUDIES. 198\%. Onderskciding van dic geesic. Hedendaagse Pinksterstrominge in Suid-Afrika. Potchefstroom : Potchefstroomse Universiteit vir Christelike Hö̈r Onderwys.

LANGERMAN, J.L. 1983. Apostolic Faith Mission of South Africa. A Revitalization of the Theological Concepts of Church Ministry. Ongcpubliseerde D.Min-verhandeling. VSA: Fuller Seminary.

LAKE, J.G. 1911. The Body of the Lord (preck). Comforter :3. March/April.

LAKE, J.G. 1911a. Church Organisation and Government. Comfoner: 1. Sept./Oct.

LAKE, J.G. [sa]. Traktaat: Goddelike genesing. Springs Adveriser.

LAKE, J.G. 1922. Adventures in God. Brief: 1 Februaric 1927 uit Thatcher, Oregan.

LE ROUX, P.L. 1921. Aantekeningen van dic editeur. Trooster : 4. April.

LE ROUX, P.L. 1928. Ondersoek dic Skrifte. Trooster : 3-4. Aug.

LE ROUX, P.L. 1934. Bro Donald Gee arrivecr in Kaapstad. Troosier. 9. Feb.

LE ROUX, P.L. 1936. Is dic Bybel (iods Woord? Kan ons daarop hou? Comforter : 5-6. Jul.

LE ROUX, P.L. 1936a. Bybclonderwys. Trooster: 30 . Spet.

MEMORANDUM, 1943. Memorandum of the Apostolic Faith Mission of SA, submitted to The National Health Services Commission of $1943: 1-5$. Oct.

MöLLER, F.P. 1955. Ons Pinkstererfenis. Braamfontein : Evangelic Uitgewers.

MoLler, F.P. 1975. Die diskussie oor die Charismala soos dit in die Pinksterbeweging gelcer en beocfen word. Braamfontcin : Evangelic Uitgewers.

MORGAN, G.D. 1934. God's Guidance. Comfonter : 19-20. Oct.

NOTULE. 1920. Werkerskonferensic. Aug.

NOTULE. 1921. Werkerskonferensic. Maarl.

NOTULE. 1926. Werkerskonferensic. Maart

NOTULE. 1936. Werkerskonferensic. April. 
NOTULE. 1954. Werkerskonferensic. April.

OPPERMAN, M. 1943. Huldeblyk oor P.L. le Roux. Comforter : 19. Jul./Aug.

SNYMAN, J.H. 1955. Memorandum. Pinkster in Suid-Afrika. Benoni (ongepublisecrd).

SNYMAN, J.H. 1956. Partypolitiek of Pinkster-Homiletick. Algemene Werckrsraad, Johannesburg (ongepubliseerd).

TROOSTER. 1921. Binnelandse Werk :11. Maart.

TROOSTER. 1930. Opening van die Bybelskool :10. Aug.

TROOSTER. 1934. Jaarlikse konferensic :6. Mei.

TROOSTER. 1938. Die Apostoliese Geloofsending van Suid-Afrika :10. Des.

TROOSTER. 1946. Advertensic : Suid-Afrikaanse Bybelkollege :24. Des.

TROOSTER. 1953. Die Apostoliese Bybelkollege :8. Sept.

TROOSTER. 1954. Ons Bybelskool :8. Maart.

VAN DER BERG, P.J. 1937. Heilige Gees manifestasies. Comforter :7-8. April.

VAN DER SPUY, M.A. 1985. Die spanning tussen vryheid en formalisering ten opsigte van die liturgiese verskuiwinge binne die Apostoliese Geloofsending van Suid-Afrika. Pretoria. (Ongepubliseerde M.Th, verhandeling. Unisa.)

VAN STADEN, A.J. 1980. Die Apostoliese Geloofsending van Suid-Afrika. Pretoria : HAUM.

VAN ZIJL, P.C. 1925. Waarom ck "Dic Wederdopers" verlaal het. OVS, Brandfort.

VERSLAG. 1930. Werkerskonferensic :1-2.

VERSLAG. 1953. Verslag van die Geestelike Komitec: Wagdicnste. Sept. 10.

VERSLAG. 1955. Verslag van dic Geestelike Komitec: Insake die klap van hande.

VERSLAG. 1956. Verslag van Geestelike Komitee: Skriftuurlike gronde vir die akticwe declname aan politick deur voliydwerkers.

WESSELS, G.R. 1955. Ons Bybelkollege. Trooster: 13 .

WILLIAMS, J.D. 1974. The Modern Pentecostal Movement in America. Lexington Theological Quanerly,9(2):50-60. 